\title{
Is France becoming more Scandinavian? \\ The Utopia of Scandinavian virtue in France-from Chirac to Macron
}

Kjerstin Aukrust and Cecilie Weiss-Andersen

\section{Abstract}

This article examines the genealogy of Scandinavian influence in France since the early 2000s and the shift in mentalities that has taken place over the last fifteen years or so regarding transparency. The analysis focuses on the notion of virtue and argues that the French representation of a virtuous Scandinavia can be interpreted as a Utopia, a counterpart that French society may use to bring about change. Whereas political leadership in France has traditionally been protected by a certain opacity and the lack of clear legislation, nepotism and corruption are no longer accepted by the French people. The main case study is the French press coverage of the Fillon scandal in the 2017 presidential campaign. The article also looks at the legislation on transparency passed under Hollande and Macron and finally asks the question: Is France in fact in the process of becoming more Scandinavian?

I prefer an accommodating vice

To an obstinate virtue

J'aime mieux un vice commode

Qu'une fatigante vertu

—Molière, Amphitryon, I.IV (1666)

"We shall become more Scandinavian." This sentence was pronounced in 2013 by French President François Hollande's entourage. ${ }^{1}$ It was the starting point for new legislation, notably on transparency, along with a general attempt to diminish the gap between the ruling class and ordinary people. Hollande was seemingly trying to transform "French political culture, a Latin culture, into a Scandinavian culture."

Hollande was not alone in this attempt. During the 2017 presidential campaign, Emmanuel Macron stated that his political project was "exactly like the Scandinavian model," adding that this Scandinavian model "works much better than ours." ${ }^{3} \mathrm{He}$ also pointed out that he saw the "moralization" of public life as one of his key tasks, thus placing transparency and openness, traditional "Scandinavian" values, at the center of his political project.

Is this a new trend? Within French politics certain factions and leaders have indeed shown interest in Scandinavian countries throughout the decades, but the French have not been accustomed to presidents wishing them to "become Scandinavian."

In this article we will concentrate on the time span from the early 2000s onward. Through the presidencies of Chirac, Sarkozy, Hollande and Macron, we will examine one aspect of the Scandinavian influence on French politics - transparency. We have cenetred our analysis on the polysemic notion of virtue. We argue that this notion has been at the core of the comparison 
between French and Scandinavian political behaviour, particularly noticeable in the French media coverage of French political scandals.

We also argue that the legislation implemented under Hollande and Macron in the domain of transparency points in the direction of a more Scandinavian turn than that proposed under Chirac and Sarkozy. This legislation came essentially as a response to political scandals and can be interpreted as an attempt to create a legal framework forcing French politicians to behave in a more virtuous manner-or, dare we say, more Scandinavian.

The use of the notion of virtue also brings a Utopian dimension into our analysis. Utopia, in the tradition from Thomas More, is an ideal society "too good to be true". Could the French representation of a virtuous Scandinavia actually be the representation of a place beyond Scandinavia itself? An ideal society, a bespoke Utopia, a counterpart that French society needs at a given time in order to bring about change?

We shall start by defining the key terms of our analysis, before we present a general comparison between France and the Nordic countries regarding transparency, corruption, and trust in politicians. This will be followed by our main case study: an analysis of the French press coverage of the scandal regarding Republican candidate François Fillon in the 2017 presidential campaign. Here, the references to Scandinavian practices were recurrent and implicitly focused on the notion of virtue. We then present main elements regarding the influence of the Scandinavian model in France since the early 2000s. Finally, we will take a closer look at some of the legislation on transparency passed under Hollande and Macron, before we ask whether Macron is in fact, as he claims, in the process of making France more Scandinavian.

\section{Method, Definitions, and Theoretical Framework}

Our main methodological approach has been to examine a selection of articles from the written press in France between 2000 and 2018 in order to analyze the image of the Scandinavian model and the Nordic countries that springs forth. One problem with the use of press material as a source is unclear or imprecise terminology. Indeed, articles often do not define what is meant by the Scandinavian model or countries, and they do not place the notion temporally. Which aspects of the model are included in a given chain of reasoning? Do they mean the model of the 1990s? The early 2000s? Or today's situation? Which of the Nordic countries do they have in mind? These are of course not the same thing, and the implications differ accordingly.

When evoking the Nordic countries and the features these societies have in common, one usually speaks of the Nordic model. Its main characteristics, according to Mary Hilson, are a predominant collectivism and conformism, a high level of political participation and organization among citizens, a relative absence of social division, and political deliberations aiming to neutralize conflict and achieve compromise. ${ }^{4}$ Some scholars prefer to speak of Nordic model $s$, in plural form: that of the welfare state model, the political model, the social model, and so on. ${ }^{5}$ The articles in the French media that we have examined mostly use the phrase "the Scandinavian model", sometimes "the Nordic model", often even "the Swedish model". 6 The term is highly elastic, and the press seems to fit a large array of elements into it, ranging from economic practices and the welfare state to the school system, environment, and gender equality. We have chosen to stick to the notion of the Scandinavian model in this article, with that same "open" meaning of "Nordic" and/or "Scandinavian." 
Our research has shown that Scandinavian countries (Denmark, Norway, Sweden) are almost systematically presented as particularly successful, exemplary, and virtuous by the French press. We therefore center our analysis on the notion of virtue. This is to be understood as "behaviour showing high moral standards" but also as "a good or useful quality of a thing" (Oxford English Dictionary). This double meaning embraces both the French interest in Scandinavian high morals and the overall image of Scandinavian societies as especially well functioning. In relation to the notion of virtue, we find it fruitful to bring the term Utopia into the analysis, "an imagined place or state of things in which everything is perfect" (Oxford English Dictionary). Etymologically speaking it evokes a good place (eu-topos) but also a place that does not exist (ou-topos). The image of Scandinavia that arises in French media, especially through the coverage of the 2017 Fillon scandal, is particularly good and virtuous. The Scandinavia that is described is almost so unnuanced that it appears surreal, a place that does indeed seem too good to be true.

We claim that by painting this positive image of Scandinavia, the French press is, in the same breath, criticizing the current state of affairs in France and implicitly promoting the idea that France would be a better place if Scandinavian practices were upheld there. This is consistent with the notion of Utopianism as defined by Lyman Tower Sargent: "a human tendency towards 'social dreaming' - the dreams and nightmares that concern the ways in which groups of people arrange their lives."7

Werner Christie Mathisen notes that depictions of Utopia represent "critical commentaries on the author's contemporary society and the developments that it is going through." "Moreover, focusing on the image of an irreproachable "North" might have cathartic qualities: when corruption and morality are addressed in a more open and direct manner than before, it could potentially lead to change. In fact, according to Lucy Sargisson, Utopias contain "challenges to the roots of contemporary socio-economic and political systems. And they intend to change the world. ... Utopias depict contrasting alternatives. These alternatives serve a double function: they hold up a mirror (to the flaws of the present) and they inspire (saying, 'things could be so much better')."

One could therefore say that the references to Nordic or Scandinavian practices in France entail an eagerness to change the current state of affairs by following their example. In the matter of transparency, this certainly seems to be the case, as we shall see.

\section{Corruption and Transparency in France and in Scandinavia}

Before we move on to our analysis, let us get some facts on the table. How different is France from Scandinavian or Nordic countries when it comes to corruption, transparency, and trust in politicians - that is, what one also might refer to as political virtue?

In Transparency International's Corruption Perceptions Index from 2018, France placed twenty-first out of 180 countries, far behind the Nordic countries - ranked first (Denmark), third (Finland and Sweden), and seventh (Norway) — and is thus among some of the most corrupt countries in the Organization for Economic Co-operation and Development. ${ }^{10}$ This echoes other studies, notably one conducted in 2009 by the International Social Survey Programme, which shows that 39 percent of French people agreed with the following statement: "To get to the top in my society, you have to be corrupt." 11 A study conducted by Ipsos in 2016 clearly illustrates the 
fact that the distrust in French politicians has been increasing the last years: here, 72 percent claimed that they found most politicians to be corrupt, and 89 percent felt that politicians mostly act to favor their own personal interests. ${ }^{12}$ These alarming numbers stand in stark contrast to the corresponding numbers in Scandinavian countries, where the level of trust toward the political elite is much higher: in Norway, for instance, the International Social Survey Programme survey from 2009 shows that only 5.4 percent of the population believed that you have to be corrupt to get to the top. ${ }^{13}$ Furthermore, Scandinavians consider their society to be fairly equal, whereas in France, the land of "liberté, égalité, fraternité," the majority tends to describe their society as a pyramid, with a small elite on top and a large majority at the bottom. ${ }^{14}$ The distance or gap between "most people" and the political elite thus seems to be far greater than in Nordic countries.

This high level of trust present in Nordic countries can be partly attributed to legislation that allows citizens to examine the income and spending of the people they have elected to represent them. In Norway, for instance, the tax assessment for every citizen, including information about income and fortune, is in the public domain and available online for all to see. ${ }^{15}$ While this type of transparency has been practiced in Norway since the early 1800 s, the famous Swedish offentlighetsprincipen goes all the way back to $1766 .{ }^{16}$ It allows Swedish citizens to access a wide range of information about their fellow citizens, such as taxes and income, information that for the most part is considered private in France. Under these conditions, it is much more difficult for politicians to keep financial secrets - the high level of transparency is there to prevent it.

Although France does not have the same type of transparency legislation deeply rooted in their history as the Nordic countries have, it still has similar laws that have been in place for a while. The "Sapin Law" from 1993 was created to improve "transparency in politics and public procurement." ${ }^{17}$ Despite the law, it was not until 2011 that Jacques Chirac was found guilty, as the first French president to be convicted of a crime, of embezzling public funds during the early 1990s. And as the Sapin Law has continued to be developed, Nicolas Sarkozy will be facing trials over allegations of illicit financing and fraud during the presidential campaigns of 2007 and 2012.

This type of presidential behaviour has made its mark on French voters. According to a survey conducted by the Institut français d'opinion publique and published by the Journal du dimanche on March 25, 2017, 63 percent of the French population found it "justified" that revelations played a "very important part" in the presidential campaign because "honesty" is a major criterion for selecting political leaders. ${ }^{18}$ There is an unmistakable gap between these opinions among the people and Chirac's assertion during his trial only a couple of years earlier, in 2011, that he had not committed any fault- "neither legal nor moral." 19 As we are about to see, revelations of immoral and possibly illegal behaviour played an important part in the 2017 campaign — changing its outcome completely.

\section{The 2017 Presidential Campaign: Morality and Transparency Take Center Stage}

The French presidential campaign in the spring of 2017 was full of surprises - the most remarkable being the election of independent thirty-nine-year-old candidate Emmanuel Macron, who was practically unknown to the French public only a few years earlier. The election of Macron was made possible in part by the fall of Republican candidate François Fillon, from a comfortable position as a favourite, to an unpleasant crash landing as a hopeless third. 
What exactly happened? On January 25, 2017, the satirical newspaper Le Canard enchaîné made the first revelations that started the scandal, ${ }^{20}$ followed by several others. Fillon was accused of creating "fake" positions for his wife and children within the National Assembly. He had employed his wife, Penelope, as a parliamentary assistant over several decades and had also employed two of his children while they were still in law school. One aspect of the scandal had to do with the practice among MPs (députés) of employing members of their family as assistants. Was it morally acceptable? Was it nepotism? Another aspect concerned doubts about whether or not these particular contracts were actually fictitious. Had Fillon's wife and children received taxpayers' money (a total of 830,000 euros in the case of wife Penelope) without doing the actual job? Was the presidential candidate guilty of embezzling public funds?

There is nothing new to the fact that French presidential campaigns contain their share of scandal. In France, politicians have traditionally been protected by a certain degree of opacity and, for decades, if not centuries, the lack of consistently enforced legislation pertaining to issues of transparency. This type of protection has been theorized by the German sociologist Georg Simmel, who recommended the use of discretion, defined as "nothing other than the sense of justice with respect to the sphere of the intimate contents of life," when it comes to certain types of citizens: "Whoever is intrusive toward a significant personality ... gives evidence of lacking capacity for appropriate respect. As the painter often emphasizes the significance of one figure in a picture that includes many persons, ... there is a sociological parallel in the significance of distance, which holds another outside of a definite sphere filled by the personality with its power, its will, and its greatness." 21 This "distance", as described by Simmel, has created a vast gap between the French people and their political representatives, and because of this, people's trust in the political elite has been meager or non-existent-being today at an all-time low, as shown by the head of Ipsos, Brice Teinturier. ${ }^{22}$ The 2017 presidential and general elections showed, however, that the French no longer accept that politicians act like an exclusive and privileged elite, placing themselves high above the people they represent.

\section{Fillon Seen in Nordic Light - by the French Media}

The media played an important part in the Fillon affair and contributed largely to the continued exposure of Fillon's misleading statements. ${ }^{23}$ The previously mentioned satirical weekly Le Canard enchaîné had a particularly decisive role, following up its longtime contribution in political revelations of fraud and other offences. It can be said to have a similar role as many Nordic press organs have, which have specialized journalists whose main job is to scrutinize the elite, for instance, by looking into the expenses of politicians. The Nordic media therefore acts as a control organ, in addition to the judiciary system. Le Canard enchaîné, with its unique position in the French media landscape, offers that same control. ${ }^{24}$

However, Le Canard enchaîné was by no means the sole media organ to cover the Fillon affair. Once the scandal broke in late January 2017, it did not take the French press long to make the connection with Scandinavia. ${ }^{25}$ "If Fillon were Swedish..." is the title of an article published by Le Monde on February 10, 2017, ${ }^{26}$ a week or so after Le Courrier international quoted a Danish correspondent stating that in Denmark, "or anywhere else in Scandinavia", Fillon would already have been "finished". ${ }^{27}$ These are only two of a number of articles in French media during this period explaining how in Scandinavia, committing a moral fault is comparable to actually breaking the law. ${ }^{28}$ French journalists thus established a link between the Scandinavian countries and transparency, morality and virtue in politics. 
References to Nordic practices were particularly frequent when the Fillon affair was at its height (February/March 2017). One of the most telling examples is an article published on the website franceinfo on February 7 titled "In Sweden, François Fillon Would Have Resigned Within Three Days, or Even Within the Half Hour!"29 According to Swedish journalist and Paris correspondent Magnus Falkehed, interviewed by franceinfo, this was not a question of morality or virtue - the Swedes are neither more honest nor more dishonest than the French. It was, rather, a question of legislation and of supervision: in Sweden, there is much less room for cheating.

As previously mentioned, this room is also narrowed by the finger pointed by Nordic journalists at politicians who behave unethically. Thus, a Swedish politician who does something wrong is quickly caught and rarely has the time or the opportunity to go very far in his or her wrongdoing. Falkehed, who characterizes France as an "imperfect democracy," reports how shocked the Swedes were that Fillon was not forced to withdraw from the presidential campaign. ${ }^{30}$ With such allegations hanging over his head, he could never have gone all the way in Sweden. When Chirac and perhaps also Sarkozy were able to embezzle public funds or to arrange illegal campaign financing in the face of existing legislation, this might suggest that the problem is a structural one, namely, a lack of supervision. The Norwegian-born magistrate and politician Eva Joly, known for her fight against corruption in France, questions the independence of the prosecuting authorities. She also highlights the cultural aspect, making it a question of moral attitude: according to her, access to higher office in France can be motivated by "the idea of personal gain." 31

The article from franceinfo is, as far as we can tell, one of the first to explicitly compare France and the Nordic countries in the specific context of the Fillon scandal. The amount of readers who have shared the article on social media is striking - and quite telling. Usually, a similar article would be lucky to reach a couple of hundred, perhaps a thousand, shares. In this case, the number is very high: it has been shared forty thousand times. The topic obviously struck a chord with a large number of French voters, for whom the comparison with the Nordic standard puts the French way of handling the situation in a very bad light. Furthermore, the fact that these types of practices had been considered normal in France, while they were severely punished in other countries, seems to be an eye-opener, as the high number of similar articles following this one attests to. Indeed, franceinfo followed up with a presentation of different cases where Swedish politicians had to resign for much less than what Fillon was accused of: drinking two glasses of wine before driving, having an illegal nanny, not paying taxes on a summer house, or owing 1,600 euros to the Swedish state, a very modest sum compared with the several hundred thousand Penelope Fillon and her children were allegedly paid from public funds for doing, apparently, nothing. ${ }^{32}$

The most frequently cited Swedish example is the so-called Toblerone affair, in which politician Mona Sahlin was forced to take a long break from politics in the mid-1990s after it was revealed that she had bought a few thousand euros worth of personal items, including the famous Swiss chocolate, on her party credit card. Although she immediately reimbursed this sum, the crime had already been committed in the eyes of the Swedish public: she was guilty of not respecting the clear limits between public funds and private spending. She resigned from her position as deputy prime minister of Sweden and retired from the political scene for nearly a decade. ${ }^{33}$ When the incident was described in the French media, the journalists seemed to imply that there was a disproportional gap between crime and punishment in this case that from a French perspective could be considered absurd. ${ }^{34}$ For the Swedes, however, the price Sahlin had 
to pay seemed appropriate: according to Joakim Sandberg from Gothenburg University, the Swedish population "expects an irreproachable ethical behavior" from their politicians. ${ }^{35}$ Could French voters expect as much? Judging by the Fillon affair, it would seem that they could not.

\section{French Grandeur Versus Scandinavian Simplicity}

If Fillon was considered a crook by some, he was by no means the first in French politics. Jérôme Cahuzac, who was budget minister under François Hollande, undoubtedly has his place among the most unpopular politicians in French history. In December 2012, it became known that Cahuzac, in charge of the fight against tax fraud, had money hidden away in Switzerland and in the Isle of Man and had lied about it on several occasions. It was estimated that assets worth 3.5 million euros had been dissimulated from tax authorities. ${ }^{36}$ Cahuzac resigned from the government in March of 2013, was excluded as a member of the Socialist Party, and was sentenced to three years in prison and five years of ineligibility in 2016.

This mandatory custodial sentence is relatively rare for a convicted French politician. ${ }^{37}$ It seems that Cahuzac received a particularly severe sentence because times had changed somewhat in France: his crime was considered worse than similar crimes committed by other politicians in the past. In fact, the French National Financial Prosecutor's Office claimed that the scandal had "sullied the honour" of France, and the judge argued that Cahuzac was adequately punished for his "exceptionally grave" error. ${ }^{38}$

After the Cahuzac affair, there seems to have been stronger interest in Scandinavian politicians, and their "simplicity and honesty", described as "pillars of politics" in an article in Le Figaro in April 2013. ${ }^{39}$ Here, Swedish ministers are portrayed as leading very different lives than their French counterparts. Almost in awe, the journalist reports that they have to eat their lunch in the cafeteria alongside their secretaries and that their meal includes neither "wine, cheese, nor dessert; only water and cold milk". One staff member claimed in the article that "if a minister were to forget to tidy up after he finished eating, you can only imagine the headlines in the newspaper the next day!"40 Moreover, the ministers' office spaces were described as being all equipped with functional IKEA-furniture - we are a long way from the gilded corridors of the Élysée Palace.

The tone and the examples in this particular article are quite typical of how the Scandinavian way of doing things used to be conceived in France: although their modest habits (they have to fly economy class - God forbid!) and virtuous behaviour were praiseworthy, they were still described with a mocking undertone. It is as though the point of these stories was to make the readers laugh, not to inspire them to demand similar behaviour from their own politicians. Can you imagine-IKEA, cold milk, and no cheese for lunch?! There seems to be a fine line between Utopia and dystopia.

The French might mock what they perceive as Scandinavian simplicity or austerity, but there has been curiosity and eagerness to learn from Scandinavian experiences over the years. We will now give an overview of how Nordic societies have been perceived in France during the last decades and to what extent one has made use, overtly or not, of the Scandinavian model as a stepping-stone toward the transformation of French society, especially in the direction of more openness and transparency. 


\section{The Scandinavian Utopia as a Catalyst for Change}

Over the years, French politicians have traveled to Nordic countries to find tools likely to help France out of the various problems that the country is facing-almost like a social laboratory from which you can pick and choose. ${ }^{41}$ A common denominator in French media seems to be that "the Nordic model" is often used in reference to difficulties experienced by France that are overcome or at least handled with a certain degree of success in Scandinavia. French interest in the Scandinavian model as a whole might be seen as the representation of an inverted mirror: Scandinavia represents the opposite of France, the positive reflection of France's shortcomings at a given time. This inverted mirror effect is one of the characteristics of the term boréalisme, as Sylvain Briens defines it. ${ }^{42}$

This process found its most recent expression in the media attention sparked and fueled by the Fillon affair, with Scandinavia as the proper place to search for the recipe for those high moral standards and practices of transparency that the French suddenly realized they were lacking - and that were possibly within reach. These depictions of Scandinavia, which we have referred to previously, showed that something could indeed be done about the problem.

In recent years, there has been an increase in international interest in the Nordic model and Nordic way of organizing society. This is often presented as a success story of prosperity and overall happiness, and the Nordic countries are seen as particularly exemplary. ${ }^{43}$ The French also emphasize Nordic success when it comes to economy and growth, welfare and the labor market, gender equality, and the environment. ${ }^{44}$

The Swedish model became well known among the French public in the 1960s and 1970s, notably through reformist journalists and politicians, such as Jean-Jacques ServanSchreiber. ${ }^{45}$ Yohann Aucante has noted that Sweden works, in France, "as a social, economic and political myth, in either a positive or a negative sense." 46 This dichotomy echoes Georges Chabot, who, in a review of the book The Swedish model by Jean Parent from 1972, suggested that the Swedish model might perhaps be more of a Swedish miracle than a model. ${ }^{47}$ No later than November 2016, Le Monde published an article claiming that "Europe is still dreaming of the Nordic model." 48 Or as the same newspaper put it in 2012, the Nordic countries are "breaking every record in the book of political fantasy." 49 These approaches add to the Utopian interpretation of what Sweden has accomplished, with the underlying idea that the Swedish way of doing things is simply too good to be quite true-or, on any account, too good to be quite suitable for export.

Be that as it may, foreign and French, interest in the Nordic countries and the North has continued to blossom. This interest has been noticeable on many levels, including on a cultural one: in recent years, Scandinavian literature and cinema, especially the sub-genre often referred to as "Nordic noir", have gained popularity. This genre - represented by authors such as the Norwegian Jo Nesbø; the Swedes Stieg Larsson, Liza Marklund and Henning Mankell; and the Danish TV series Forbrytelsen - seem to fascinate, among other things, because of the contrast between a society that is harmonious and transparent on the surface and the terrible crimes and misery hidden underneath.

Another feature of Scandinavian culture that fascinates outside the Nordic countries is the Danish/ Norwegian concept of hygge and the Swedish term lagom, which are currently a hot topic in France, particularly in the field of self-improvement: ${ }^{50}$ if you can adopt the Scandinavian lifestyle, you will enjoy life's simple pleasures and be happier. There is convergence between 
these simplistic references and the depictions of a social and economic model of society that promotes prosperity and well-being.

There is undoubtedly a pro-Nordic wind blowing in France. Let us now take a closer look at what shape the political dimension the Nordic inspiration has taken during the last fifteen years or so, through the prism of the last three French presidents, before considering the current one.

The Scandinavian Model in France: From Discreet Inspiration to Conspicuous "Branding" Although they were not sworn advocates of the Nordic model, both President Jacques Chirac (two presidential mandates, 1995-2002 and 2002-2007) and his successor Nicolas Sarkozy (2007-2012) drew inspiration from the Nordic countries, each in his specific manner. Magnus Falkehed has shown, for instance, how the main axes of priorities determined by Chirac for his second term, such as road safety, cancer prevention and integration of disabled people - were all fields of action in which Sweden had already been a pioneer for several years. ${ }^{51}$ As for Sarkozy, commentators have identified some of his reforms as emanating from the "Scandinavian model," 52 even though he himself is said to have openly preferred the German way of doing things. ${ }^{53}$ And indeed, Alain Lefebvre claimed in the early 2000s that "there are Nordic elements in twothirds of all social reforms taking place in France today." 54

During the first three years of Chirac's second presidential term, no fewer than ten ministers, including the prime minister, visited Nordic countries for inspiration in matters of defense, research, equal rights and opportunities, the labor market, education, and technology. ${ }^{55}$ Nevertheless, a search through French press during this period does not seem to yield any official declarations from the government pertaining to a particular inspiration that the government could be drawing from the North. ${ }^{56}$ It is interesting to note that the French Right did not more explicitly discuss its influences from a Nordic model largely rooted in longtime social democratic rule.

One might, however, claim that there was a certain form of Nordic inspiration on Nicolas Sarkozy's part, even though he himself did not make any specific mention of this. Nonetheless, in 2007, Sarkozy stated in a campaign video that he wanted to make France into "an irreproachable republic." 57 A couple of months later he argued that he intended to put "morality back into politics." 58 This echoes the virtuous conduct that the French press was later to attribute to the Scandinavian countries. Meanwhile, in a retrospective overview of Sarkozy's five years in office, Transparency France concluded that some progress was to be noted but that there was still not sufficient political willingness to work against corruption. ${ }^{59}$ The quest for an irreproachable republic was a campaign promise that Sarkozy did not keep. ${ }^{60}$ Accusations regarding the funding of his presidential campaign and others tarnished the image of an irreproachable president. Columnists seemed to agree that what was accomplished was quite the opposite of irreproachability, evoking the possible espionage, bribes, and favouritism that Sarkozy has been accused of. ${ }^{61}$

If Sarkozy looked to the North, it seems that it was not so much as a source for inspiration in economic or social matters, as it had been for Chirac, but as a rhetorical device, that of morality, virtue and irreproachability, strongly associated with the Nordic countries. It was all in the discourse and not so much in actual political measures - a means of utilizing the powerful topic of morality to "brand" his political action. 
"We Shall Become More Scandinavian"

As France was preparing for the presidential election of 2007, the Socialist Party had already spent the previous years defining a political platform under the leadership of its first secretary, François Hollande. He was openly inspired by what the Socialists themselves defined as the "Scandinavian model." ${ }^{2}$ In a 2005 interview with Le Monde, one of the party leaders stated: "We obviously draw inspiration from successful political experiments. Sweden, for example, is able to create jobs and financial wealth while ensuring a high level of social security and improving the quality of education and research." ${ }^{63}$ In 2006, one year ahead of the elections, Ségolène Royal founded a think tank (Ségonordic) with the explicit aim of identifying best practices from Nordic politics. Royal was much criticized for her Nordic inclinations at that time and was rapidly and pejoratively labelled as "Blairist." 64

After replacing Nicolas Sarkozy as president in 2012, Hollande made several references to the North. For instance, he declared that he intended to draw inspiration from the reforms of northern Europe by cutting public spending while safeguarding France's social model. ${ }^{65} \mathrm{Le}$ Monde noted in April 2013 that France was "torn between Latin compromise and Nordic virtue", and was going to undertake an operation of "transparency" toward more social democracy. ${ }^{66} \mathrm{At}$ that time, Emmanuel Macron was deputy secretary-general of Hollande's government, and he set out to "get a country that is stuck in a rut moving again." ${ }^{" 77}$ France was, indeed, stuck, as the Socialist government tried to put forth new labor legislation that turned out to provoke massive protests from the French people (the El Khomri bill). Nevertheless, significant parallels with the Scandinavian model also came from elsewhere.

In 2013, the Hollande government approved a series of measures to ensure more transparency and integrity in public life (Lois relatives à la transparence de la vie publique). ${ }^{68}$ This did not, however, come unmotivated. It was a direct consequence of the Cahuzac scandal earlier that same year. Hollande, who during the presidential campaign had promised to turn France into an "exemplary Republic", lost face. He needed to act. The new measures made it more difficult for banks to hide transactions carried out in tax havens, and all government ministers were made to publish a detailed list of all their assets for the first time in French history, as well as their activities, in order to rule out conflicts of interest. Each minister's income was made public. Hollande also took initiative to set up an administrative body aiming to ensure integrity amongst French public officials, the High Authority on Transparency in Public Life (La Haute Autorité pour la transparence de la vie publique). Moreover, a special prosecutor for financial crimes was appointed. ${ }^{69}$ In 2016 came the next step in Hollande's endeavor to make France a more transparent society, the Sapin II law, Lois relatives à la transparence, à la lutte contre la corruption et à la modernisation de la vie économique. ${ }^{70}$

Hollande placed his mandate under the auspices of normality. He was the "normal president," who made sure to stop at red lights and take the train more often..$^{71}$ Le Monde quotes journalist Philippe Moreau Chevrolet, who noted that there had been a shift from "normality" to a kind of "normalism" defending a "Utopian vision" of French political life, with "selfless and modest" members of parliament who were to "lead the same everyday life as citizens" and were to "concentrate on their duties." It was a model à la scandinave, where a minister "jumps on his bike after work, hoping to get home in time to put his children to bed." 72 However, the "flaw" with this concept of a "normal presidency," according to journalist Jean-Luc Mano, is the fact that it is "terribly demanding" and difficult to sustain in the long run. ${ }^{73}$ 
By focusing on being a "normal" president, Hollande took ownership of conduct that was likened to the Scandinavian way of doing things. His endeavors toward more transparency were in a similar vein, paving the way for Macron's later efforts, which we will get to shortly. In fact, he was also constructing the very rules and structures that would later lead to the fall of François Fillon, through the creation of the High Authority on Transparency in Public Life in 2013, requiring MPs to name their associates with a view to avoiding conflicts of interest. ${ }^{74}$ In a report published as Hollande's governmental period was coming to an end, Transparency International summed up the positive results pertaining to transparency during those five years, noting that a "culture change" had been initiated. ${ }^{75}$ A shift was on its way.

Current President Macron has consistently repeated that he represents a break with the politics of Hollande, even though he was part of his team for a period of time, last as minister of economy, industry, and digital affairs (August 2014 to August 2016). The two presidents nevertheless appear to have a shared enthusiasm for the Scandinavian model. On March 3, 2017 , when Macron had just published substantial parts of his political platform, Le Monde printed the following front-page headline: "Macron Wants to Import the Scandinavian Model". A key element of this platform consisted in reforming pension and unemployment schemes, as well as fully revising the organisation of the labor market. These measures were explicitly borrowed from the Scandinavian model, as economist Jean Pisany-Ferry from Macron's team confirmed. ${ }^{76}$ But did he only talk the Scandinavian talk, or did he actually walk the walk? Let us take a closer look at the measures proposed and implemented by Macron in terms of transparency and morality.

\section{Macron: Making the Nordic Utopia a French Reality?}

While the Fillon affair was at its height, Macron based parts of his campaign on the promise of new laws, which were to "bring back morality to public life" and combat conflicts of interest. ${ }^{77}$ This commitment came partly as a result of his alliance with François Bayrou, the leader of the centrist party Mouvement démocrate, who has worked for more transparency in politics over several years. In fact, one of the four requirements Bayrou asked Macron to meet before they formed an alliance was to implement a "moralization law" (loi de moralisation de la vie publique) aimed at promoting probity in French politics. Macron agreed, stating that French voters were now insisting on more morality in politics. Once elected, Macron made Bayrou minister of justice and gave him the task of implementing a policy of "zero tolerance" in this field. ${ }^{78}$

The purpose of such proposed laws was to clean up the murky morals of French politics and to "end nepotism" in the political field by imposing a ban on MPs and senators employing family members or working as consultants while in office. ${ }^{79}$ The law could be seen as the continuation of the similar laws implemented by Hollande in 2013 and 2016 (and in fact initiated under Mitterrand in the form of the previously mentioned Loi Sapin I), but going even further in legislating France's policy of transparency. ${ }^{80}$ To be fair, the level of ambition was initially quite high. For instance, any person convicted of fraud, tax evasion, or similar offences would be punished more severely than before: banishment from public office for ten years. Other proposed measures included a new maximum of three terms for MPs and senators and making it illegal to hold multiple offices at the same time.

In May 2017, Bayrou pointed to the fact that, for years, the country had "seen practices develop that have damaged people's confidence in their elected representatives and provoked a 
profound exasperation among the French." 81 The aim was to reestablish this confidence, and this was also reflected in the name that Macron's transparency laws were ultimately given: Lois pour la confiance dans la vie politique. It is interesting to note the change from transparence, "transparency", under Hollande, to confiance, "confidence", or "trust," under Macron. This trust factor is one of the key parameters of the Nordic model and a frequently evoked point when attempting to explain the reason for the success of Nordic welfare states. ${ }^{82}$

Bayrou was right: these new moralization laws were much anticipated by French voters and would very much fill a gap in French legislation, making France, one could argue, more "Nordic". However, Macron quickly met with unexpected trouble within his own ranks. Four of his newly named cabinet members had ethical dilemmas of their own, accused of nepotism and of having illegally employed party operatives as parliamentary aides. ${ }^{83}$ As a result, several ministers, including Bayrou, were forced to step down after the parliamentary election in June.

When the laws were voted on August 9, 2017, the president of the National Assembly, François de Rugy, tweeted "Mission accomplished" — but was it? Although the "morality" laws do represent a step in the right direction, they did not in fact fulfill all of Macron's promises. Alain Lefebvre, who wrote an entire book on Macron's Swedish tendencies, claims that the laws turned out to be a missed opportunity for France to actually become more Nordic. ${ }^{84}$ Although the Scandinavian inspiration was certainly there, the implementation was not. For instance, pension privileges for retired senators still prevail (while they have been abolished for the National Assembly's députés), and the ban on employing family members is only valid for MPs, not for political groups or locally elected politicians. The much-talked-about laws therefore seem to be rather lackluster compared with the high level of ambition. One might thus conclude, as the MP from the centrist party Union des democrats et indépendants Philippe Vigier did, that the laws were "not a revolution but a healthy evolution." 85 They were a step in the Nordic direction but not quite Nordic yet.

\section{Can Macron Really "Import the Scandinavian Model"?}

We have already seen how "there are Nordic elements in two-thirds of all social reforms taking place in France today," according to Lefebvre. The latter also emphasized, however, that there is "never any direct transposition." ${ }^{86}$ In her book Le rebond du modèle scandinave, Marie-Laure Le Foulon uses the example of Danish flexicurity (flexisécurité), a principle that "contains all the characteristics on which the welfare state is founded," in order to illustrate that it is not possible to transpose the Nordic welfare state onto France. ${ }^{87}$ First, the percentage of workers affiliated to trade unions is much lower in France than in the Nordic countries. ${ }^{88}$ What is more, according to Le Foulon, France lacks the tendency of the Nordics to favor consensus and cooperation. The country, she argues, does not share the Nordic ideals of equality or their visceral allergy to marked hierarchies: you will not find the characteristically Nordic principle of mutual respect between leaders and employees in France, nor will you find an equivalent tradition of social dialogue between the different actors in the labour market. ${ }^{89}$

As Jean-Marc Vittori puts it in Les Échos in 2006: "Certain ideologists recommend importing the complete model. That is more easily said than done, because in the Swedish social model, you also have... The Swedes." Vittori stresses, with the words of economist Robert Boyer, that the Nordics are equipped with an "exemplary public spirit," or civisme exemplaire. ${ }^{90}$ This civic exemplarity, or virtue if you will, does not seem to be shared by all French parliamentarians. As Lefebvre points out, it was the députés themselves who stood in the way of 
the previously mentioned moralisation laws becoming a blueprint of the Nordic legislation: whereas Scandinavian politicians are almost considered the voters' employees, since they are paid by the voters' tax money, French politicians are still eager to place themselves in an untouchable position, high above their electorate. ${ }^{91}$

A public report written in 2011 by a commission led by Jean-Marc Sauvé, vice president of the Conseil d'État, aiming at preventing conflicts of interests, stressed the fact that the pursuit of transparency in politics must not become "an unfair quest for virtue." In fact, he considered it a danger that this quest could become "suspicious or excessively intrusive." 92 This attitude among French politicians seems to prevail several years later, as illustrated by the reactions of several MPs in 2017 to the suggestion of more scrutiny of parliamentary expenses, similar to Scandinavian practices. Some expressed concern and annoyance that the new rules might lead to a "climate of suspicion," verging on a dictatorship of openness. ${ }^{93}$ It thus seems that the transparency French politicians are looking for is not necessarily an equivalent to the Nordic one but, rather, a French, more "tempered" version. ${ }^{94}$

If these examples tell us one thing, it is that it is to a large degree the French politicians themselves and the political culture they are a part of that stand in the way of Macron's project of appropriating the Scandinavian model. However, this is not the only obstacle in his way. Just before the 2017 election, Le Monde published a piece in which political scientist Bruno Palier explained the ways in which Macron's announced reforms were, if not impossible, then unScandinavian: Macron lacked a "global logic based on equality." 95 Another article in the same newspaper described why it would be so difficult for France to reproduce the Scandinavian model at home, ${ }^{96}$ pointing to differences in terms of social dialogue and traditions of reform as well as the lack of a typically Nordic "culture of consensus." 97 It thus seems that Macron's endeavors toward a more Scandinavian France still have a long way to go.

\section{Conclusion}

Transparency and the political behavior that should come with it are arguably among the key features of the so-called Nordic or Scandinavian model. In this article, we have claimed that there has been certain movement toward Scandinavian transparency policies in France and that the public, through the media, seem to encourage this shift. But is it even possible for a country such as France to "import" features of Scandinavian societies? According to the Norwegian sociologist Jon Elster, the Scandinavian model simply cannot be exported. He insists that Nordic models depend on the equilibrium of several deeply intertwined factors. It would not make sense to borrow separate elements here and there without ensuring that the other prerequisites for proper balance are in place. ${ }^{98}$ Another key argument in this article has therefore been that the search for a more Scandinavian type of political behavior, or a more virtuous one, is Utopian, in the sense that it is unrealistic, as long as the other factors necessary for transparency in politics (for instance, cultural) are not present.

Yet societies are dynamic, as are cultural attitudes and practices. Lucy Sargisson notes that Utopias are not necessarily to be realized, and they are not necessarily "blueprints for a perfect society." Utopias do, however, "seek to change the world," and this might just be one factor contributing to the shift that has been taking place in France. ${ }^{99}$ References and inspiration 
from Scandinavian societies show what is possible when it comes to transparency and morality and might just contribute, along with other converging factors, to the initiation of change.

As we have seen in this article, the Nordic countries have served, and still do, as an example of ideal values and desirable practices within different domains, at different times. The 2017 French presidential campaign was one of those times. For a few intense weeks the Nordic countries were projected as the ultimate example of how things could be done differently in terms of transparency and morality. They became the Utopia of France, a kind of idealized place of absolute virtue. François Fillon became the embodiment of French politicians stuck in an old world of privilege and double standards, failing to see that times are in fact changing. Or as L'Express put it: "The political mores are changing," and François Fillon, "clinging to a closing chapter" in history, "does not understand this." 100 However, one cannot overlook the fact that although Fillon was indicted for fraud, stigmatized by the media, and punished by part of his electorate, he still finished third in the presidential election. Could that have happened in Scandinavia? Our guess would be no.

Fillon, who had been the favourite to win the 2017 elections, was beaten by newcomer Emmanuel Macron. As we have just seen, Macron's Nordic convictions are certain, but how far do they go? One cannot claim that Macron's presidential mandate has evolved completely along Nordic lines. The Yellow Vest protests that started in November 2018, initially against fuel taxes and tax reforms, and the violent clashes between protesters and the police have made it clear that Macron has an authoritarian and hierarchical take on social dialogue compared with the Nordic countries. Also, Macron's many sarcastic or scornful remarks about the unemployed, or other vulnerable groups, are at odds with the Scandinavian way of dealing with those who fall behind. His premier de cordée metaphor (regarding the lead climber, who in turn pulls up the ones who come after him), describing the society he wants, is not particularly egalitarian. ${ }^{101}$ Neither are his nicknames, "Jupiter" and président des riches, which illustrate Macron's inability to diminish the gap between the French people and the political elite — a gap that is, as we have seen, much smaller in Scandinavia.

It thus seems that it is not, in fact, Macron who is making France more Scandinavian but, rather, the French people themselves. They are the ones who now reject immoral conduct in politics and who demand more openness. Scandinavia, and its virtuous image, which is presented to them through the press, is the French people's Utopia. Because this shift of mentalities is taking place among the people, one might be optimistic about the probability that it will develop into sustainable changes. The aptitude and willingness of the political leadership to pursue and carry out the implications of this are, however, a source of more uncertainty.

Kjerstin Aukrust is an associate professor of French literature and area studies in the Department of Literature, Area Studies and European Languages, University of Oslo, Norway. She has published several articles on French politics, the French sixteenth and seventeenth centuries, and French contemporary literature.

Cecilie Weiss-Andersen is a Ph.D. candidate in French area studies in the Department of Literature, Area Studies and European Languages, University of Oslo, Norway. She is affiliated 
with an interdisciplinary research project studying how the Nordic countries and the Nordic model are received and debated in Europe (EURONOR).

Notes

${ }^{1}$ Arnaud Leparmentier, "Hollande, faux social-démocrate ?," Le Monde, April 17, 2013, http://www.lemonde.fr/idees/article/2013/04/17/hollande-faux-social-democrate_3160999_3232.html. Unless otherwise noted, all translations are ours.

${ }^{2}$ Philippe Moreau Chevrolet, "L'art du 'normal': François Hollande et Valérie Trierweiler pris à leur propre piège," Le Nouvel Observateur, June 8, 2012, http://leplus.nouvelobs.com/contribution/567516-1-art-du-normal-francoishollande-et-valerie-trierweiler-pris-a-leur-propre-piege.html.

3 “Interview d'Emmanuel Macron sur France Inter," April 21, 2017, https://en-marche.fr/articles/discours/matinalefrance-inter-macron-21-avril-attentats.

${ }^{4}$ Mary Hilson, The Nordic Model: Scandinavia Since 1945 (London: Reaktion Books, 2008).

${ }^{5}$ Oddbjørn Knutsen, ed., The Nordic Models in Political Science. Challenged, but Still Viable? (Oslo: Fagbokforlaget, 2017), 12, 264.

${ }^{6}$ For historical reasons, notably the particular interest of journalist Jean-Jacques Servan-Schreiber in the 1960s, Sweden has been more debated in France as an exemplary society than the other Nordic countries. See Alain Lefebvre, Macron le Suédois (Paris: PUF, 2018), 40.

${ }^{7}$ Lyman Tower Sargent, "The Three Faces of Utopianism Revisited," Utopian Studies 5, no. 1 (1994): 3, quoted in Lucy Sargisson, Fool's Gold? Utopianism in the Twenty-First Century (Basingstoke, U.K.: Palgrave Macmillan, 2012), 8.

${ }^{8}$ Werner Christie Mathisen, "Utopier—noe for statsvitere?" Norsk statsvitenskapelig tidsskrift 22, no. 4 (2006): 423.

${ }^{9}$ Sargisson, Fool's Gold? 8.

${ }^{10}$ Transparency International, “Corruption Perceptions Index 2018,” https://www.transparency.org/cpi2018.

${ }^{11}$ International Social Survey Programme, "Les inégalités sociales. Résultats commentés" (2009), http://www.isspfrance.fr/wp-content/uploads/2014/02/ISSP2009_fr_resultats.pdf.

${ }^{12}$ Brice Teinturier and Vincent Dusseaux, Fractures Françaises 2016, vague 4 (Ipsos/Sopra Steria pour Le Monde, La Fondation Jean-Jaurès, and Sciences Po, 2016), https://www.ipsos.com/sites/default/files/files-fr-

fr/doc_associe/fractures_francaises_2016.pdf.

13 "Dataset: Social Inequality, 2009, Norwegian Part of ISSP,“ Norske spørreunders $\varnothing$ kelser, http://nsddata.nsd.uib.no/webview/?submode=abstract\&mode=documentation\&study=http://nsddata.nsd.uib.no/obj/f Study/NSD1460\&mode=documentation.

${ }^{14}$ Johs. Hjellbrekke and Olav Korsnes, "Intergenerasjonell https://www.lemonde.fr/politique/article/2011/09/23/emplois-fictifs-jacques-chirac-nie-toute-faute-morale-oupenale_1576952_823448.html mobilitet og sirkulasjon i norske elitar og profesjonar," in Elite og klasse $i$ et egalitcert samfunn, ed. Olav Korsnes, Marianne Nordli Hansen, and Johs. Hjellbrekke (Oslo: Universitetsforlaget, 2014), 56.

${ }^{15}$ See "Skatteoppgjør," Skatteetaten, http://www.skatteetaten.no/no/Person/Skatteoppgjor/Sok-i-skattelistene/Hvastar-i-skattelistene/, for details about the nature of this public information.

${ }^{16}$ Alf Bohlin, Offentlighetsprincipen [Principle of openness], 9th ed. (Stockholm: Norstedts Juridik, 2015).

${ }^{17}$ See Sapin II Law : Transparency, The Fight Against Corruption, Modernisation of the Economy, April 6, 2016, https://www.gouvernement.fr/en/sapin-ii-law-transparency-the-fight-against-corruption-modernisation-of-theeconomy.

${ }^{18}$ Laurent Neumann, Les dessous de la campagne 2017 (Paris: Calmann Lévy, 2017), 340.

19 "Emplois fictifs: Jacques Chirac nie toute faute morale ou pénale, jugement le 15 décembre," Le Monde, September 23, 2011, https://www.lemonde.fr/politique/article/2011/09/23/emplois-fictifs-jacques-chirac-nie-toutefaute-morale-ou-penale_1576952_823448.html

${ }^{20}$ See https://www.lecanardenchaine.fr/la-une-du-25-janvier-2017/.

${ }^{21}$ Georg Simmel, "The Sociology of Secrecy and of Secret Societies," American Journal of Sociology 11, no. 4 (1906): 453-454. 
${ }^{22}$ Brice Teinturier, Plus rien à faire, plus rien à foutre. La vraie crise de la démocratie (Paris: Robert Laffont, 2017).

${ }^{23}$ See, for instance, Heidi Taksdal Skjeseth, "All the President's Lies: Media Coverage of Lies in the US and France," Reuters Institute Fellowship Paper, University of Oxford, 2017.

${ }^{24}$ Laurent Martin, “Le Canard Enchaîné” ou les Fortunes de la vertu-Histoire d'un journal satirique 1915-2000 (Paris: Flammarion, 2001).

25 The articles we have examined mainly refer to the Scandinavian countries - Denmark, Norway, and Swedenusing both the term Scandinavian and Nordic. They most often refer to the three aforementioned countries, and to a lesser extent, the other Nordic countries.

${ }^{26}$ Anne-Françoise Hivert, "Si Fillon était suédois...," Le Monde, February 10, 2017, http://www.lemonde.fr/mmoyen-format/article/2017/02/10/si-fillon-etait-suedois_5077946_4497271.html.

${ }^{27}$ Corentin Pennarguar, “Au Danemark, Fillon serait cuit il y a longtemps,” interview with Danish Paris correspondent Bjørn Willum, Le Courrier international, January 31, 2017, https://www.courrierinternational.com/article/interview-au-danemark-fillon-serait-cuit-depuis-longtemps.

${ }^{28}$ According to Alain Lefebvre, there were at least thirty references to Sweden in connection with the Fillon scandal (Macron le Suédois, 19). This essay only covers a sample of these articles.

${ }^{29}$ Raphaël Godet, "En Suède, François Fillon aurait démissionné dans les trois jours, voire dans la demi-heure!" franceinfo, February 7, 2017, https://www.francetvinfo.fr/politique/francois-fillon/affaires-fillon/en-suede-francoisfillon-aurait-demissionne-dans-les-trois-jours-voire-dans-la-demi-heure 2052289.html.

${ }^{30}$ The quality of French democracy has also deteriorated over the last several years in the eyes of the French population. See, for instance, the survey "Dissatisfaction with Democracy in France (2009-2016)" (CEVIPOF Baromètre de la confiance politique 2009-16), referred to in Jocelyn Evans and Gilles Ivaldi, The 2017 French Presidential Elections. A Political Reformation? (Basingstoke, U.K.: Palgrave MacMillan, 2018), 23.

${ }^{31}$ See Vincent Daniel, "Pourquoi est-il si difficile de moraliser la vie politique française?" franceinfo, June 4, 2017, https://www.francetvinfo.fr/politique/affaire/affaire-richard-ferrand/pourquoi-est-il-si-difficile-de-moraliser-la-viepolitique-francaise 2218569.html.

${ }^{32}$ Benoît Zagdoun, “Affaire Fillon: Pourquoi la Suède est-elle considérée comme un modèle de transparence en politique?” franceinfo, February 9, 2017, https://www.francetvinfo.fr/politique/francois-fillon/affaires-fillon/affairefillon-pourquoi-la-suede-est-elle-consideree-comme-un-modele-de-transparence-en-politique 2054515.html.

${ }^{33}$ For details, see Mikael Romero, Tobleroneaffären. Varför Sverige inte fick sin första kvinnliga statsminister (Stockholm: Norstedts förlag, 2012).

34 The humorous titles often given to articles that refer to the case illustrate this point (for instance, Antoine Jacob, "En Scandinavie, on ne badine pas avec l'éthique," Les Échos, May 25, 2016, https://www.lesechos.fr/25/05/2016/LesEchos/22198-050-ECH_en-scandinavie--on-ne-badine-pas-avec-1ethique.htm\#; and Guy Belloy, "Pas de chocolat pour les ministres suédois...," Le blog de Guy Belloy, July 3, 2012, https://blogs.mediapart.fr/guy-belloy/blog/030712/pas-de-chocolat-pour-les-ministres-suedois).

${ }^{35}$ Interviewed in Jacob, "En Scandinavie, on ne badine pas avec l'éthique."

${ }^{36}$ Les Décodeurs, “Affaire Cahuzac: Des révélations au jugement," Le Monde, December 8, 2016, http://www.lemonde.fr/les-decodeurs/article/2016/12/08/affaire-cahuzac-resume-des-episodesprecedents 5045933 4355770.html.

37 Tracy McNicoll, "French 'Tax Tsar' Turned Political Pariah Jérôme Cahuzac Back in Court for Appeal,” France 24, February 12, 2018, http://www.france24.com/en/20180212-france-cahuzac-tax-fraud-tsar-hollande-ministerpolitical-pariah-court-appeal.

38 Ibid.

${ }^{39}$ Stéphane Kovacs, “'Normal' comme un ministre suédois,” Le Figaro, April 9, 2013, http://www.lefigaro.fr/international/2013/04/09/01003-20130409ARTFIG00284-normal-comme-un-ministresuedois.php.

40 Ibid.

${ }^{41}$ Falkehed uses the notion of a "social and economic laboratory" to describe French interest in Swedish reform practices. Magnus Falkehed, Le modèle suédois (Paris: Payot, 2005), 9.

42 Sylvain Briens, "Boréalisme. Le Nord comme espace discursif," Études Germaniques 282, no. 2 (2016): 179-88.

${ }^{43}$ World Happiness Report 2019 (U.N. Sustainable Development Solutions Network with the Ernesto Illy

Foundation, March 20, 2019), http://worldhappiness.report/download/.

${ }^{44}$ Based on our archive searches in French newspapers and magazines between 2000 and 2017.

${ }^{45}$ Lefebvre, Macron le Suédois, 39. 
${ }^{46}$ Yohann Aucante, “'Den svenska modellen' i fransk samhällsvetenskap: En översikt," in Sylvain Briens and Mickaëlle Cedergren, Médiations interculturelles entre la France et la Suède: Trajectoires et circulations de 1945 à nos jours (Stockholm: Stockholm University Press, 2015), 30.

${ }^{47}$ Georges Chabot, "Le modèle suédois, de Jean Parent,”.Annales de Géographie 81, no. 445 (1972): 356-57.

${ }^{48}$ Marie Charrel, "Le modèle nordique fait toujours autant rêver l'Europe," Le Monde, November 26, 2016, http://www.lemonde.fr/economie/article/2016/11/26/le-modele-nordique-fait-toujours-autant-rever-1europe_5038524_3234.html.

${ }_{49}$ Olivier Truc, "Les Scandinaves, champions du marketing politique, jouent les modestes," Le Monde, February 20, 2012, http://www.lemonde.fr/economie/article/2012/02/20/les-scandinaves-champions-du-marketing-politiquejouent-les-modestes 1645697 3234.html.

${ }^{50}$ Some of the French books on this subject are Le Livre du lagom; Lagom, vivre mieux avec moins; Hygge, se réjouir des choses simples; Hygge: l'art du bonheur danois; Le livre du Hygge; and Hygge, l'art de vivre à la scandinave.

${ }^{51}$ Falkehed, Le modèle suédois, 10.

52 Jean-Marc Vittori, "Le modèle nordique, trop exigeant pour la France?" Les Échos, June 28, 2006, https://www.lesechos.fr/29/06/2006/lesechos.fr/200078282 le-modele-nordique--trop-exigeant-pour-la-france.- htm.

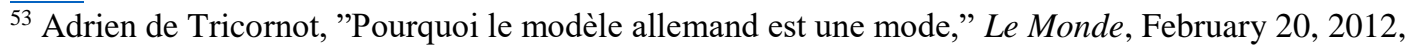
http://www.lemonde.fr/economie/article/2012/02/20/pourquoi-le-modele-allemand-est-unemode_1645684_3234.html.

${ }^{54}$ Quoted in Marie-Laure Le Foulon, Le rebond du modèle scandinave (Paris: Éditions Lignes de repères, 2006), 149 .

${ }^{55}$ Falkehed, Le modèle suédois, 9.

${ }^{56}$ The three main national newspapers Le Monde, Le Figaro, and Libération. Ideologically speaking one might see why a right-wing president would not want to talk too loudly about his social democratic inspirations, but this question deserves an analysis of its own that would be too long for this article.

${ }_{57}$ Sarkozy soutient Fillon pour une République irréprochable, uploaded by jmichel2you, YouTube, April 10, 2017, https://www.youtube.com/watch?v=iglMNHnYEqg.

${ }^{58}$ Magistrates Matthieu Bonduelle and Benoist Murel, "La 'République irréprochable,' pour mémoire," Le Monde, opinion column, April 26, 2012, http://www.lemonde.fr/idees/article/2012/04/26/la-republique-irreprochable-pourmemoire_1691151_3232.html.

${ }^{59}$ Transparency International France, "Bilan du quinquennat en matière de lutte contre la corruption," Transparency International, February 29, 2017, https://www.transparency.org/news/pressrelease/20120229_bilan.

${ }^{60}$ According to journalists such as Thomas Legrand (Radio France Inter) and Ruth Elkrief (BFM TV). "Quel bilan pour la 'République irréprochable' de Nicolas Sarkozy," slateFR, March 30, 2012,

http://www.slate.fr/france/52441/republique-irreprochable-sarkozy-bilan,

http://www.dailymotion.com/video/xkvtme.

${ }^{61}$ AFP, "Ces scandales qui ont assombri le mandat que Sarkozy voulait irréprochable," Le Point, February 6, 2012, http://www.lepoint.fr/politique/ces-scandales-qui-ont-assombri-le-mandat-que-sarkozy-voulait-irreprochable06-02-2012-1428014_20.php.

62 "Jack Lang: Nous devons tenir un langage de vérité et de courage," Le Monde, September 28,

2005, http://www.lemonde.fr/societe/chat/2005/09/26/jack-lang-nous-devons-tenir-un-langage-de-verite-et-decourage 693087 3224.html.

${ }^{63}$ Ibid.

${ }^{64}$ Isabelle Mandraud, "Ségolène Royal vante le blairisme et prend le PS de court," Le Monde, June 3, 2006, https://www.lemonde.fr/societe/article/2006/02/03/segolene-royal-vante-le-blairisme-et-prend-le-ps-decourt 737604 3224.html. There is much to be said about the interest in Nordic social democracy on the left in France, but that would be too vast for the scope of this article.

${ }^{65}$ AFP, “Modèle scandinave: Où est passé l'Etat providence?" Le Point, January 20,

2014, http://www.lepoint.fr/economie/modele-scandinave-ou-est-passe-1-etat-providence-19-01-2014-

1781891_28.php\#xtatc=INT-500.

${ }^{66}$ Leparmentier, "Hollande, faux social-démocrate?"

67 "Remettre en mouvement une France crispée"- perhaps the premise already of Macron's movement "En Marche!" which was to be established in April 2016.

${ }^{68}$ See LOI no 2013-907 du 11 octobre 2013 relative à la transparence de la vie publique (1), May 23, 2019, https://www.legifrance.gouv.fr/affichTexte.do?cidTexte=JORFTEXT000028056315. 
${ }^{69}$ See Loi organique et loi ordinaire du 11 octobre 2013 relatives à la transparence de la vie publique, November 5, 2015, http://www.vie-publique.fr/actualite/panorama/texte-discussion/projet-loi-organique-projet-loi-relatifstransparence-vie-publique.html.

${ }^{70}$ See Tout savoir sur la loi \#Sapin2, https://www.economie.gouv.fr/transparence-lutte-contre-corruptionmodernisation.

${ }_{71}$ Anne-Sophie Mercier, "La normalité de François Hollande, une posture piégée," M. Le magazine du Monde, August 18, 2012, http://www.lemonde.fr/m-styles/article/2012/08/18/la-normalite-posturepiegee 1747190 4497319.html? xtmc=scandinave hollande normal\&xtcr=3.

${ }_{72}$ Ibid. This echoes the opening scene of the program Complément d'enquête by the French broadcaster France 2, showing Knut Storberget, who was the Norwegian minister of justice at the time, finishing his workday early in order to pick up his children from nursery school: Norvège, une démocratie sous surveillance, April 2, 2007, http://www.ina.fr/video/3320753001006.

${ }^{73}$ Mercier, "La normalité de François Hollande."

${ }^{74}$ Mathilde Mathieu, "L’Assemblée a rémunéré 52 épouses, 28 fils et 32 filles de députés en 2014," Mediapart, July 27, 2014, https://www.mediapart.fr/journal/france/270714/lassemblee-remunere-52-epouses-28-fils-et-32-filles-dedeputes-en-2014?onglet=full.

${ }^{75}$ Louise Bodet, "L'association de lutte contre la corruption Transparency France tire un bilan positif du quinquennat," franceinfo, December 19, 2016, https://www.francetvinfo.fr/politique/affaire/cahuzac/informationfranceinfo-l-association-de-lutte-contre-la-corruption-transparency-france-tire-un-bilan-positif-duquinquennat_1975307.html.

${ }^{76}$ Laurence Geai, "Macron veut importer le modèle scandinave," Le Monde, March 3, 2017.

${ }^{77}$ See Macron's political program, https://storage.googleapis.com/en-marche-fr/COMMUNICATION/ProgrammeEmmanuel-Macron.pdf, 26-27: "Une démocratie rénovée."

${ }^{78}$ Adrien Gaboulaud, "Bayrou, ministre de la moralisation... et de la tolérance zéro," Paris Match, May 17, 2017, http://www.parismatch.com/Actu/Politique/Bayrou-ministre-de-la-moralisation-et-de-la-tolerance-zero-1259657.

${ }^{79}$ Rédaction Europe 1/AFP, "Macron veut interdire l'emploi de proches aux parlementaires pour 'mettre fin au népotisme,"” Europe 1, March 2, 2017, http://www.europe1.fr/politique/presidentielle-emmanuel-macron-veutinterdire-lemploi-de-proches-aux-parlementaires-pour-mettre-fin-au-nepotisme-2991758.

${ }^{80}$ The law's full name was La loi n $93-122$ du 29 janvier 1993 relative à la prévention de la corruption et à la transparence de la vie économique et des procédures publiques.

${ }^{81}$ Kim Willsher, "Macron Unveils 'Moralisation Law' in Drive to Clean Up Politics," Guardian, June 1, 2017, https://www.theguardian.com/world/2017/jun/01/french-prosecutors-open-inquiry-into-macron-ally.

82 The European Social Survey from 2014 shows that Denmark, Finland, Norway, and Sweden have the highest scores in terms of social trust (from 6.3 to 6.9 out of 10), whereas France is further behind, with a score of 4.6 out of 10. See http://www.europeansocialsurvey.org/data/download.html?r=7.

${ }^{83}$ Gregory Viscusi, "Macron's Clean Image Tested as Two Ministers Come Under Fire," Bloomberg Politics, May 30, 2017, https://www.bloomberg.com/news/articles/2017-05-30/macron-s-clean-image-tested-as-two-ministerscome-under-fire.

${ }^{84}$ Lefebvre, Macron le Suédois, 20.

${ }^{85}$ Baptiste Legrand, "Moralisation de la vie politique: Une loi et des espoirs déçus," L'Obs, August 10, 2017, https://www.nouvelobs.com/politique/20170810.OBS3242/moralisation-de-la-vie-politique-une-loi-et-des-espoirsdecus.html.

${ }^{86}$ Quoted in Le Foulon, Le rebond du modèle scandinave, 149.

${ }^{87}$ Ibid., 152.

${ }^{88}$ According to the Organisation for Economic Co-operation and Development, in 2013, 68 percent of workers in Sweden, 67 percent in Denmark, and 52 percent in Norway were members of a trade union, whereas 8 percent of French workers were. Fafo Research Foundation, http://www.arbeidslivet.no/Lonn/Fagorganisering/Organisasjonsgrad-og-tariffavtaledekning/.

${ }^{89}$ Le Foulon, Le rebond du modèle scandinave, 152.

${ }^{90}$ Vittori, "Le modèle nordique".

${ }^{91}$ Lefebvre, Macron le Suédois, 20.

${ }^{92}$ Jean-Marc Sauvé, Pour une nouvelle déontologie de la vie publique, Rapport de la Commission de réflexion pour la prévention des conflits d'intérêts dans la vie publique, January 26, 2011, https://www.hatvp.fr/wordpress/wpcontent/uploads/2016/02/Rapport-Commission-Sauve.pdf, 11.

${ }^{93}$ AFP, "Remboursement des frais de mandat des députés: Stéphane Le Foll se plaint de devoir garder ses factures," franceinfo, December 4, 2017, https://www.francetvinfo.fr/politique/moralisation-de-la-vie- 
politique/remboursement-des-frais-de-mandat-des-deputes-stephane-le-foll-se-plaint-de-devoir-garder-sesfactures_2497955.html.

94 "Une transparence bien tempérée." See Yves Poirmeur, "La transparence dans le discours politique actuel," in $L a$ transparence en politique, ed. Natalie Droin and Elsa Forey, (Paris: Institut Universitaire Varenne, 2013), 110.

${ }^{95}$ Frédéric Joignot, "Bruno Palier: 'Il manque à Emmanuel Macron la logique globale du modèle scandinave, fondé sur l'égalité," Le Monde, April 8, 2017, http://www.lemonde.fr/election-presidentielle-

2017/article/2017/04/08/bruno-palier-il-manque-a-emmanuel-macron-la-logique-globale-du-modele-scandinavefonde-sur-l-egalite 5108040 4854003.html.

${ }^{96}$ Marie Charrel, "Les secrets de la flexisécurité scandinave," Le Monde, March 4, 2017, http://www.lemonde.fr/economie/article/2017/03/04/les-secretsde-la-flexisecurite-scandinave 5089237 3234.html.

${ }^{97}$ Lefebvre (Macron le Suédois) also notes that Macron's Scandinavian solutions are in fact outdated in the Nordic countries.

${ }^{98}$ Jon Elster, "Le modèle scandinave ne peut pas s'exporter," Le Monde, May 21, 2013, https://www.lemonde.fr/idees/article/2013/05/21/le-modele-scandinave-ne-peut-pas-s-

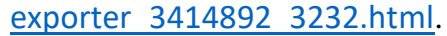

${ }^{99}$ Sargisson, Fool's Gold? 8.

${ }^{100}$ Christophe Barbier, "Il n’y a pas eu d'affaire Fillon il y a un an," editorial, L'Express, January 24, 2018.

https://www.lexpress.fr/actualite/politique/il-n-y-a-pas-eu-d-affaire-fillon-il-y-a-un-an-1-edito-de-christophebarbier_1978998.html.

${ }^{101}$ Lefebvre, Macron le Suédois, 256. 